\title{
THE VOCABULARY LAYER OF THE KHOREZM KIPCHAK DIALECT
}

\section{${ }^{1}$ Zarifboy Dosimov, ${ }^{2}$ Shahnoza Alimova}

${ }^{1}$ Professor, Department of Uzbek Linguistics, Urgench State Univeristy, Urgench, Uzbekistan.

${ }^{2}$ Lecturer, Department of Uzbek Linguistics, Urgench State Univeristy, Urgench, Uzbekistan.

\begin{abstract}
This article provides detailed information about the peculiarities of Khorezm kipchak dialects of the Uzbek language. For instance, the phonetic, lexical and grammatical features of lexis in the under research dialect are highlighted basing on the examples. The given examples are compared with the options in other dialects. In this article dialect words are given in Cyrillic letters while the literary language forms of words are given Uzbek alphabet in Latin letters, in order to avoid confusion in pronunciation with English sounds of these letters.
\end{abstract}

Keywords:

dialect, dialect, kipchak, classification, phonetic features, lexical features, morphemic features, singormonism.

Article Received: 18 October 2020, Revised: 3 November 2020, Accepted: 24 December 2020

\section{Introduction}

At present, Khorezm is inhabited by the representatives of the Oghuz and Kipchak dialects of the Uzbek language. Although these people live in an area very close to each other, they still retain their distinctive linguistic features, despite the fact that there are continuous economic and cultural ties between them. Linguistically examining these dialects, scholars speculate that the lexicon of these dialects contained elements of Arabic and Persian, which are not found in the central Uzbek dialects, and there are assumptions that such words came from the ancient Khorezmiy language. [1:12].

The historical, archeological and ethnographic research carried out in recent years raises the issue not only of the relationship of Khorezm dialects with other Turkic peoples, but also their relationship with non-Turkic peoples, including those living in East Asia and Eastern Iran. [1: 130]. In general, the ethno-genesis of the peoples of the Aral Sea region (Karakalpak, Uzbek, Turkmen) goes back to antiquity, which is not yet clear, which is explained by certain historical conditions. Due to this region, with its geographical conditions, was a place where different ethno-genetic and cultural relations collided. [3:27]. Therefore, the study of dialects formed in such conditions in the historicallinguistic plan will undoubtedly yield important results.

It is known that many Uzbek dialects are perfectly studied. However, we cannot say the same about some dialects, including Khorezm Kipchak dialects, which have not been fully studied in all its aspects. Although much work has been done on the Oghuz dialect of the Khorezm dialects, only a few notes have been made about the Kipchak dialects.

H.Doniyorov classifies the Kipchak dialect of the Uzbek language in general, basing on the views by N.A. Baskakov, F.Abdullaev, V.V.Reshetov on Kipchak dialects in general and their types and features, and divides Kipchak dialects into five general types. He classifies the Khorezm Kipchak dialects as the North Khorezm type (northern Khorezm Kipchak dialect). [5:12]. He claims that Kipchak dialects were studied by E.D. Polivanov, F.Abdullaev, A.Ishaev and Y.Ibragimov, and it is necessary to include Kipchak dialects in Karakalpakstan to this type. In his opinion, this type differs from other Kipchak dialects by the abundance of Oghuz elements in Kipchak dialects. [5:12]. 
According to the language features, people belonging to the Kipchak dialect of the Uzbek language live mainly in Gurlan, Yangibazardistricts as well as in some villages of Shovot and Bagat districts in Khorezm region, Beruni, Amudarya, Khojayli, Kungrad and partly Shumanay districts and Nazarkhan village of Nukus district of Karakalpakstan. These dialects differ to some extent fromeach other in some linguistic features. For this reason, researchers classify them as Beruni-Mangit, Khojayli-Kipchak and Kungrad dialects. [4: 5]. In this classification, the Gurlan-Yangibazar dialects located in the territory of Khorezm region, as well as the dialects of other districts were ignored. Although the researcher A. Ishaev noted that the full classification of these dialects will be covered in detail in another work, for some reason it was not published anywhere. [4: 5].

This study is the result of our observations on Kipchak dialects in Khorezm region and does not claim a perfect solution.

Phonetic features. Khorezm Kipchak dialects differ from the dialects that are the basis of the literary language in terms of the number of vowels. That is, they have 6 vowels, in Khorezm dialects 9 vowels: [и, ы, э (е),y, y, о, ө , a, ә ]

\section{Materials and methods}

The researchers studying Khorezmian dialects note that there are phonemes $[и, ы]$, the back of the language, as well as the mid tongue variants of the sound in the language. [6:15]. In fact, there is a slightly back-to-back version of this vowel in the dialect. Compare: ийначи (lit. ninachi-grasshopper), ийт (lit. it- dog), ийә p (lit. egar-saddle), сыйлы (lit. izzatli-honorable) and others.

It should be noted that there are only secondary elongated vowels in Khorezm Kipchak dialects, which are formed sporadically (do not have the feature of meaning differentiation). They are the result of the fall of consonant sounds such as $[\mathrm{X}, \breve{\mathrm{h}}]$ in the dialect, as well as the addition of two consecutive vowels in some words to form secondary elongated vowels. For example: сә :p (lit. sahar-morning), шә :p (lit. shahar-city), мә нат//мийнат(lit. mehnat-labor), сә :т//ca:т(lit. soat-hour), мә :мала (lit. muomala-treatment), қ ана:т (lit. qanoat-satisfaction) and others

There are no primary long vowels in the dialect that differ in meaning. F. Abdullaev classifies Khorezm dialects according to their phonetic-morphological and lexical features, divides Kipchak dialects into sound й-[j]-added and ж-[dj]-added types. The "ж" dialects spoken in Akkum northeast of Marbutat village, northwest of Vazir village in Gurlan district, as well as the Chinese part of Kipchak (now Amudarya) district of Karakalpakstan, northeast and south of Mangit district, and their specific language features are presented in detail. (2: 259264). He points out that these dialects retain the main features of the ' $j$ '-added Kipchak dialects, as well as acquire distinguishing features also. In particular, in some words, the [ж] at the beginning of the word is systematically converted to [й] (jag in literary, йағ in dialect)

" й " added dialects. Representatives of these dialect type make up $10 \%$ to $40 \%$ of the population in Gurlan, Mangit and Kholimbek districts of Amudarya district, Yangibazar district, as well as in almost every district in the south of Khorezm, as well as in Kipchak district of Karakalpakstan (northwest of of China settlement) and in many parts of Beruni and Turtkul districts. They also live in large areas in the Dashoguz district (now Niyazov district) of Dashoguz region in Turkmenistan. [2: 262]

F. Abdullaev points out that these dialects retain the main features of the "ж"-added Kipchak dialects, as well as their differences:

1) The vowels $[и]$ and $[\ddot{y}]$ are "soft" sounds prone to the tongue, but not at the pre-i and $\ddot{y}$ level in the Oghuz dialect.

2) Diphthongation is much weaker, it is difficult to feel the diphthongation of the vowels e, ö, o at the beginning of a word in fast speech. 
3) “й” added form, i.e. yer not жер (yer-earth), уо`l not жол (уо `-way) (but jiyda, jiyna). With the exception of addition of sound [ж] in some words, the $\%$ found at the beginning of a word encountered in the first type of dialects is systematically converted to [й](even in the literary language the word жағ is pronounced as йағ in Gurlan).

4) The sound $[x-k h]$ is separated from $\left[\xi_{l}\right]$ as an independent phoneme.

5) - ning affix of the genetive case in some villages of Mangit district, Gurlan district and some villages of Yangibazar district, mainly stable in speech as an episodic feature(in other parts it is replaced with accusative affix-ni ), the full version of the genetive suffix is preserved in the spoken languge of older generation.

6) The short variant of the affix of the accusative case $(-и+\mathrm{H},-\mathrm{c}+и н)$ is usually absent.

7) the declension of the noun in the $3^{\text {rd }}$ person is formed by the affixes -нӓ н // -иннӓ н, -синнӓ н in the possessive pronoun.

8) affix -ватир // -ятир are used to form the verb in present tense

9) affix -тоғ ин // -тағ ан used to form the adjective of the future tense

10) affix -ганча // -ғ анча (two affixes are used depending on the final consonant of the word in the Oghuz dialect: сорағ анча, галинча.

In addition, prof. F. Abdullaev points out that in the "й"added dialects, even in Gurlan district, there are some phonetic features characteristic of Oghuz dialects: däväräk, eddi. In fact, the phenomenon $t>d$ at the beginning of the word is typical feature of Oghuz dialects. The scientist argues that this is the result of the interaction of the dialects.

Prof. F. Abdullayev is a well-known dialectologist linguist who studied Khorezm dialects, introduced them to the world, expressed great theoretical ideas on these dialects, and was the first to create a more complete dictionary of words in Khorezm dialects. But over time, as in all areas, changes occur in dialects for a variety of reasons.
In this regard, it is necessary to emphasize the impact of school-education, changes in society, the development of science, the media. In addition, the territory of Khorezm region has changed significantly since the master scholar F.Abdullayev invested the dialects here. The Amudarya district, which was once part of Khorezm region, was later transferred to the Republic of Karakalpakstan. It is natural that all these changes would have an impact on the classification of Khorezm Kipchak dialects and the language of the people living in this area.

We included the dialects of Gurlan and Yangibazar districts of Khorezm region as the object of our research. There are elements of [ж]addition in people's speech living in the villages of Gurlan district located in the north of Khorezm and in some parts of it bordering on Amudarya district, more precisely, in Dosimbiy settlement.

Once the people of North Khorezm, and even Uzbeks in Central Khorezm, including Gurlan district, spoke a common [ж]-added dialect. Under the influence of the Middle Khorezm Oguzs dialects the dialect lost its [ж] feature and began to use [й] instead of [ж]. [10:42] A similar opinion was expressed by the linguist $R$. Yoldashev, who conducted research on the lexicon of Uzbek dialects in the Dashoguz region.[8: 5-6]

It should be understood that the main reason for the decline of "ж" from North Khorezm to Khiva is the existance of people speaking by adding "ж" in the areas bordering the region, as well as the influence of the neighbouring Karakalpak language. [4:12]

In addition, there is another dialect type with “ä" pronunciation introduced by F.Abdullayev as the third type of Kipchak dialect types. F. Abdullayev noted that there are not many such dialects, mainly in the villages of Shangi and Kangli in Gurlan district, as well as in the Arab settlements of Kipchak in Urgench district, Monok in Shavat district, Naiman in Bagat, Qatagan in Kushkupir, Kangli (Pitnak) in 
Khazarasp. a characteristic feature is the constant use of the sound [ä] instead of [e] in the first syllable of the words as (кӓ л -kel, тамир -lit. temir). [2: 265-266]

As can be seen, [a] added dialect types also exist in Northern Khorezm. In addition, representatives of this type of dialect live in the village of Oyrat in Yangibazar district.

Thus, the dialects we are studying belong to the [й] added dialects, the [ä]-added dialects, which is characteristic of the third type of dialects, as well as the Kipchak dialect types, which in some words retain the phenomenon of diphthongization, which is characteristic of the [ж] -added dialects.

E.D. Polivanov calls the presence of [ж]assimilation in Khorezm Kipchak dialects "Kazakhized" dialects due to the signs of nonpreservation of the consonant $[\mathrm{x}]$ at the beginning of the word. [7: 5]. Indeed, the Khorezm Kipchak dialect types are radically different from the Kazakh language with a number of unique linguistic features. This is obviously seen in areas where the Uzbek, Kazakh and Karakalpak peoples live in the same area sharing the settlement. Compare: the dialect words Юмиртов, йиланли

The feature of "Kazakhization" is not observed at all Gurlan, Yangibazar districts, as well as in the settlements and the villages of Kilichboy and Halimbek in Amudarya district. This fact is also confirmed by the dialect materials. Compare: places names in the dialect as in the words, Юмиртов, Йиланчи, Хитой, Хўжақ алъа, Халимбек.

The linguist A. Ishaev rightly objected to this problem. In the local Kazakh language these words are used in the form of Джумуртов, Джиланли, Қитай, Қожақ алъа, Қалембек, Шарвак. That is, it is possible to observe the correspondence of the consonants [й $/ / ж-\mathrm{j} / / \mathrm{d} 3$ ], $[\mathrm{x} / / \mathrm{K}-\mathrm{kh} / / \mathrm{q}],[\mathrm{\varphi} / / \mathrm{\omega}(\mathrm{ch} / / \mathrm{sh})]$ at the beginning of the word.

It should be noted that vocalic harmony is preserved in Khorezm Kipchak dialect types, and the vowels has back (soft, hard) variants of pronunciation in the dialect. According to historical data, in certain periods the population of North Khorezm spoke some Middle Khorezm Uzbek dialect in [ж] added type. However, under the influence of the Oguz dialect types, they lost their [ж] properties and switched to [й]. A similar opinion was expressed by R. Yuldashev. [8: 5-6]

According to F.Abdullaev, the third type of Khorezm Kipchak dialects is [a] type.The representatives of this dialect type are not so numerous among population and they live in the villages of Shangi, Kangli (Gurlan), Kipchak (Urgench), Naiman (Bagat), Monoq (Shovot), Qataghan (Koshkupir), Kangli (Pitnak), Oyrat (Yangibazar). One of the features of this type of dialect is the regular use of the sound [a] instead of (e) in the first syllable of the word: käl instead of kel, тамир -instead of temir, китади -ketadi.

In some cases, the historical etymological sound $[\breve{и}]$ is preserved in the dialect: yil-jil, yuzum, yilon / jilon. Also an increase in the [й] sound between words is observd. For example: Miybozor, Biyvatan, biychora, diwana, biybi and others.

The sounds $r, 1$ do not occur at the beginning of the word. The words that have the r, 1 sound at the beginning of a word will inevitably appear in front of them with a prosthetic vowel. Ўрозбой-lit. Ro`ziboy(name. Roziboy), Иражабlit. Rajab (name.Rajab), Ўрис- lit. rus (Russian), Илай-lit.ilon (mud), Илақ қ a-lit. laqqa (sheatfish), Иланпачи (Lanpachi- a lamp repairman) and others.

There are also some lexical peculiarities in the studied dialect. In particular, I, you, he differ from other Turkic languages when these pronouns are varied with the directional conjunction (-a): men + ga (моң a), sen+ga (соң a), unga (вуң a), shunga(шуң a). Compare the words with the Kazakh соғ ан, karakalpak соғ ан, nughay соғ a. Assimilated forms of words минан instead of bilan with; апки instead of olib kel, apkit instead of lit. olib ket) are also more active, as well as the 
words with the dialect suffix -джақ (келаджақ,борджақ) instead of literary kelmoqchi, bormoqchi

In general, Khorezm Kipchak dialects have almost invariant forms in the literary language and in other Turkic languages. It is the emergence of the form of grades that has attracted the attention of some linguists in the dialect type. E.D. Polivanov considers the pronunciation of the word 'lit. bolalar'(children) in the form of 'baf alar' as a result of the phenomenon of dissimilation: (лал->ғ ал) [9:17].

F. A. Abdullaev explains this case as following, neither the length of vowels when the consonant 1 falls from the stem, nor the sequential position of two vowels in the word 'bolalar' is not typical for Kipchak dialects. Accordingly, a glottal sound $[\mathrm{h}]$ appeared between the [a] vowels in the stem, and then it sounded: [bolalar >баалар> бох алар > боғ алар] [2: 146].

According to A.G. Gulyamov, the form of the word "bola"(child) has the plural (-lar) suffix the same as usual, but the difference is that it is added to the Mongolian form of the word "bola" (боғ алар - bolalar (children)) [10:12].

Ahmad Ishaev writes that the word 'bala' has the Mongolian form бурят, baf a (bagha) and the suffix Turkic suffix -лар was added to the Mongolian stem word and now it is preserved in the dialect in the form of ' боғ алар'. [4:31]

There are peculiar features of word-makers in Khorezm Kipchak dialect types. In particular, there is vocalic harmony in most of the affixes with hard and soft clusters of consonants as in other Uzbek dialects.

-мә н//-ман йилқ иман (horseman), билармон (braggart);

-чә //ча маң лайча (scarf tied to the forehead), тумчә (choynak- kettle or vessel made of cast iron or aluminum used for boiling water on fireplace from the word туң - water pot);

-лә с//-лас бийтлә с (a man with lousy clothes), буртлас//муртлас (shop mo`ylov- thickmustache); -ламә //-лама бирлама (yaganalashsingling out) борлама (davomat-to check the attendance);

-лик//-лық отынлиқ (woodland),

тўғ айлиқ (woodland);

-чил//-чыл гапчил (talkative), ўйчил (a person who thinks a lot);

-мә //-ма ағ дарма, сузмә (a type of pilaf), созма(rubber) and others.

In general, if we compare the word forming affixes in the Uzbek literary language and other Uzbek dialects, they differ in a number of features, such as the presence of phonetic variants, the width of the scope of application, as well as the width of the functional scope. For example, the -лық affix corresponds to the -zor affix in literary language. Тоғ айлық, оि тыллиқ However, the affix -лық is also used in the making of professional lexis, such as башлық (chairman), о ллиқ (brigadier), the noun denoting possessiveness майлиқ (hand towel), сувлиқ (the part of the strap tied around the horse's mouth), қ алиң лиқ (from the word density). There are also many syntactically compound words in Sheva. Compare: қ улақ чанақ (pot), қ уртбағ ар (cocoon-keeper), қ арриқ из, нангўш (melon varieties), пайапил (bridge), кийимбаш (clothes), йармақ апи (door) and so on.

It is known that the main part of the lexicon of the Uzbek literary language and Uzbek dialects consists of units common to all Turkic languages. Example: ата (father), қ из, мен, алти, сари (yellow), алтинтов (mountain), тари (tariq), баш, кӧ з (еye), and so on.

\section{Result and discussion}

This opinion can be confirmed on the basis of written monuments of Turkic languages. Note the work "Devonu lug'otit Turk": қ ара (black 1.46), ажа (palm, 1.142) ириң (pus, 1.154), сағ из (gum, 1.345) and so on. Mahmud Kashghary wrote 900 years ago: "...the most accurate and clear language is only the language of those who know it, do not mix with the 
Persians, and do not have the habit of going to and from cities." (DLT, I, 65). This idea still remains a guide for researchers studying dialects.

It should be noted that most of the ideas and conclusions presented in Devon apply to all Turkic languages and their dialects. In order to draw such conclusions, which are common to the Turkic languages, it was necessary, of course, to make a comparative study of these languages. In other words, Mahmud Qashqari's work on the comparative study of Turkic languages, the research done nine centuries ago is still one of the most important manuals for the contemporary linguists. These and similar facts allow us to say that Mahmud Kashgari was a great dialectologist not only for his time, but for all periods in the study of Turkic languages and their dialects.

It is noteworthy that the words in the Uzbek literary language such as тоғ, тош, яхши, ёмон, юпқ а, яшил, қ ор, қ ўзи, яна, кундуз, йўқ, ёлғ он, қ из, сўз, болдиз are used in Devon by Mahmud Kashgari as they exist in presentday Kipchak dialect, although with slight phonetic differences. The following words are almost identical in Devon with the modern Uzbek literary language and dialect forms. Compare:
In Devon: тирик(alive), ӧлӥк(dead) (И, 54), кичик(small) (I, 119), эллик(fifty) (I, 160), ачиғ (bitter) (І, 94), сариғ (yellow) (И, 335), улуғ (great) (I, 95).

In Kipchak dialect: тири(alive), ӧли(dead), киччи(small), элли(fifty), аччи(bitter), сари(yellow), улуғ (great). As you can see, it's almost the same except for a few phonetic changes.

It is known that in Khorezmian (Kipchak) dialect the consonant $y$ is used before words beginning with vowels like $\mathrm{i}$ and $\mathrm{y}$. Mahmud Kashgari emphasizes that this consonant has existed in Turkish words since ancient times. This means that the consonant $y$ is not acquired at the beginning of words such as йилимақ, йип, йилан, йилик in the dialect, these consonants have been present in these words since ancient times.

Many words preserved in Kipchak dialect can be found in written monuments, including Devon. There are many words that are common to the Devonian lexicon and the Kipchak dialects of the Uzbek language, and the following are examples for this case:

\begin{tabular}{|c|c|c|}
\hline \multirow[t]{2}{*}{ In "Devon" } & in Kipchak dialect with & \multirow{2}{*}{ In Literary the Uzbek } \\
\hline & sound & \\
\hline кӱн $(I, 327)$ & кун & quyosh, oftob(the Sun) \\
\hline не $\quad$ (III, 233) & не & nima?(what?) \\
\hline бал $\quad$ (III, 171) & бал & asal (honey) \\
\hline жумуртғ а (III,439) & юмурта & tuxum (an egg) \\
\hline жапурғ ақ (III, 58) & япрақ & barg (a leaf) \\
\hline
\end{tabular}

It is difficult to separate the dialect vocabulary stock from the main dictionary of the Uzbek language. But even so, there are a lot of words that belong to the dialect itself. The lexical structure of the Kipchak dialect in GurlanYangibazar district of Khorezm region can be compared with the lexical structure of the literary language in three different ways:
1) Words that do not differ from the literary language forms: bosh(head), tosh(stone), qir (edge), bil(know), bilim(knowledge), men(I), bu(this), besh(five) qirq (fourty);

2) Words that differ from the literary language form in their phonetic variants: белбов- belbog (waistband), бувдай-bug'doy(wheat), ўёвuyg`oq(awake); 
3) The dialect specific words жоิ рраб, шангил, тимақ, ул.

If we look at nomadic and pastoral words in the dialect, we find commonalities with Kipchak-type with neighjboring languages, and in particular with Uzbek dialects with initial [j] sound instead of $[y]$.

Certainly, the basis of the vocabulary of Kipchak dialects is the original Turkish and original Uzbek words. Although the words in the dialect have in common with the literary language and other dialects in the fields, sometimes their peculiarities come to the fore.

However, there are many words in the dialect dictionary that do not change in the Uzbek literary language. It is not correct to call such words dialectal words, as many of such words have been borrowed from other languages. They are words of our language from the distant past. For example: далан (corridor covered with between the gate and the house), дандан, дә дан (tooth), дасмал (potter), дасқ ap (male sparrow), кә чкэрт (sickle, small sickle), кә ззап (swindler, vile), сархум (mug), қ алтаман (thief, pickpocket), ӱр (stubborn, obstinate), аран(corral, pound, stables) and so on.

It is known that the Turkic languages the Kipchak dialect type are lexically very close to each other. However, the vocabulary of these languages also includes terms that are not found in other languages or differ in meaning. But they also differ in the sources and quantity of the words they borrow from other languages. (4:17). We think another fact should be noted here. The economic, cultural and especially historical ethnic relations of the Kazakh, Nogai and Karakalpak peoples with the Khorezmian Kipchak dialect representatives date back to ancient times. Therefore, it is natural that tribal names and place names such as Kipchak, Kangli, Uyshun, Kungrad, Qitay, Qirq, Achamayli, Bolghali have been preserved in the language of the people living in this area. The fact that such ethnic parallels are preserved in the common language of the Nogai, Kazakh, Karakalpak and other Turkic peoples, as well as the Uzbeks of Northern Khorezm, confirms this idea.
N.A.
Baskakov,
F.Abdullaev,

A.M.Shcherbak, A.M.Shacherbak, O.Madrahimov and other scientists who studied Khorezm dialects considers such words as арна, чел, мә нджирә , кундә , кэт, далан, хараз, лабър (loop) words related to the Tajik language. These elements show that the Turkic tribes in Central Asia emerged as a result of their strong ties with the Iranian tribes.[2: 141]. Prof. O. Madrahimov notes that many words in the lexicon of Khorezm Oghuz dialects belong to the ancient Khorezmian language.

The words belonging to the lexical layer of the Tajik language are much deeper than Arabic words and are organically mixed with the lexical structure of Kipchak dialects. Like all Uzbek dialects, Tajik words are the words used in every day, every hour vital cases. Such words have a strong place in the lexicon of dialects and are used in literary language with or without a slight phonetic change. Such words can be included here: нан(bread), гуман(doubt), худа(God), зӓдӓ(bored), зӓрдӓ(heartburn), дӓстӓ(handle), пир(saint), постин(sheep-wool coat), рӓсва (scandalous), пияз(onion), асман(the sky), apäстӓ(chic), ашна(pal), ӓнжам (tool), пай(peer), пахса(wall), бахит(happiness), чилим (hubble-bubble), дар(noose), pô за(fasting), шад(exhilarated), чӓн(vat), тухум(seed), палас(a large rug), банги(hemp addict), баж(dues), базар(bazaar), паян(fag-end), айна(mirror), жуван(young lady), пар(feather), зиндан(dungeon), бӓд(bad).

There are also many words used in dialects that have undergone phonetic changes. These are pronounced according to the phonetic rules of the dialects: х ӓ:к (lime), дӓрваз (gate), аташкир (otashkurak), кӓпкир (original kaftgir means skimmer), кӓпчӓ (original kaftcha means 
spade), хоржин (valise), ӓстӓн (slowly), қ ондақ ( hump), käptär (dove), ӓптада (aftado), macha (female), абрай (reputation) and so on.

Some of the Persian-Tajik words actively used in our research object belong to the passive layer in other regions dialects, as well as in the literary language. The list of such words include: дӓндӓнӓ (flattenning with wood), хараз (wheat(rice)mill), пазза (hammer tooth), гуппи (a short wintercoat sewn with cotton inside), дӥкарт (ironmade scissors), кӓчкарт (a type of sickle), кӥрpа (donkey cub), пешгир (pinafore), чангғ алақ (cotton swab), абиш (hug), тӓртӓнӓк (spider), топпиш (wintercap), замариқ (mushroom), замча (handalak-an early summer melon), курта (children's wear sewn of cotton cloth and cotton itself inside), кӓриз (drainage ditch), паяпил (small wooden bridge to cross ditch), силапча (a small basin for handwash)

Indeed, there is no doubt that these lexical units are related to Iranian languages. Our observations have always shown that elements of the ancient Khorezmiy language have been preserved in this dialect. Although the Khorezmiy language was completely mixed and assimilated with Turkic languages in the XIII-XIV centuries, many lexical and grammatical elements are preserved in the dialect lexicon of today, especially in the onomastic system. Undoubtedly, this confirms that the language belongs to the family of Iranian languages, more precisely, to the East Iranian network. [11:11]. If we study these units from the historical-etymological point of view, it allows us to say that there is a separate lexical layer in the dialect. Based on the properties of this layer, we can call it the tag layer of the Khorezm dialect lexicon, i.e. the substrate layer.

At the present time, as in all areas, the process of language integration is in progress. The rapid development of science and technology, the emergence of various means of communication between people, in particular electronic means, led to the convergence of local dialects. Uzbeks,
Karakalpaks, and Turkmens, Kazakhs, and other ethnic groups have long lived together in the areas we study. So the progressive process is reflected in the speech of the dialect representatives. In their language there are words typical of Kazakh, Turkmen, Karakalpak languages. They are used with various phonetic changes and are adapted to the pronunciation of the dialect representatives. The linguist S. Arazkuliev who studied the Turkmen dialects in Khorezm in all linguistic aspects notes that the Uzbek language has a strong influence on the language of igdir, dusji, goklan tribes of the Turkmen. In the second type of dialects, the boundaries of the language are gradually disappearing, and becoming the dialects of the Uzbek language. [12: 5-17].

\section{Conclusion}

Thus, Uzbek dialects are gradually losing their original features and merging within the literary language. This also raises the issue of collecting rich materials of dialects.

\section{References}

[1] Vamberi A. Travels in Central Asia in 1863. In Russian, Saint Petersburg, 1865, p.130-135

[2] Abdullaev F. Khorezm Dialects of the Uzbek Language, in Uzbek, Tashkent, 1961, p.236

[3] Tolstov S.P. In Search for Ancient Khorezm Culture, In Uzbek, Tashkent, 1964, p.27

[4] Ishaev A. Uzbek Dialects in Karakalpakstan. In Uzbek Tashkent, 1977, p.3

[5] Doniyorov X. The Vocabulary of the Kipchak Dialect, In Uzbek Tashkent, 1979, p.12

[6] Abdullaev F. The Classification Problems of the Khorezm Dialects (Materials from Uzbek Dialectology, in Russian), Tashkent, 1960, p.15

[7] Polivanov E.D. .... Kiyat, Kungrad, Shavat Districts in Khorezm region, the Uzbek 
SRICC, Volume of Scientific Papers. Issue 1, issue 2, Tashkent, 1934 p.56

[8] Yuldashev R. The "J" Phenomenon in the Dialects of the Uzbek Language Spoken in Tashkent Region, in Uzbek, Uzbek Language and Literature, 1993, Issues 5-6.

[9] Polivanov E.D. Some Phonetic Features of the Karakalpak Language, in Russian, Tashkent, 1933, p.17

[10] Polivanov E. D. Material on the Grammar of the Uzbek Language, in Russian, Issue 1. Introduction. Tashkent, 1935

[11] Gulomov A. Plural Category in Uzbek Language. In Uzbek, Tashkent, 1944, p. 12

[12] Do'simov Z. Khorezm Toponyms. In Uzbek, Tashkent, 1985, II

[13] Anazkuliev S. Turkmen speakers in Turtkul District in Karakalpakii. AKD, 1962, Pp. 5-17

[14] 14. Madrahimov O. Oghuz Dialect of the Uzbek Language. In Uzbek, Fan, Tashkent, 1973. 